\title{
Efektifitas Cahaya Lampu LED untuk Pengendalian Penggerek Buah Citripestis sagittiferella pada Jeruk Rimau Gerga Lebong (RGL)
}

\author{
Desnada Satria ${ }^{1 *}$, Dwinardi Apriyanto ${ }^{1}$, Supanjani $^{1}$ \\ ${ }^{1}$ Program Studi Agroekoteknologi, Fakultas Pertanian, Universitas Bengkulu \\ *Corresponding author: desnadasatria1995@gmail.com
}

\begin{abstract}
Abstrak
Penelitian ini bertujuan untuk mengevaluasi efektifitas cahaya lampu LED + reflector (compact disc) sebagai salah satu alternatif untuk mengendalikan penggerek buah pada jeruk RGL dan pengaruhnya terhadap insidensi serangan lalat buah.Penelitian ini dilaksanakan pada Agustus 2020 sampai November 2020 di kebun jeruk gerga milik Bapak Darlin di Desa PAL VII, kecamatan Bermani Ulu Raya, kabupaten Rejang Lebong, provinsi Bengkulu ketinggian lahan \pm 1000 mdpl. Tanaman jeruk berumur 6 tahun ketika penelitian dilaksanakan, sudah berproduksi dan terawat baik dengan jarak tanam $5 \times 5$ meter. Pelaksanaan penelitian diawali dengan memasang instalasi listrik yang diberikan lampu pada tanaman sampel pada beberapa titik pengamatan di lokasi penelitian. Lampu yang telah dipasang dinyalakan setiap hari dari pukul 18.00-06.00 WIB dari tanggal 10 Agustus sampai 10 November 2020. Kemudian dilakukan pengamatan serangan penggerek dan lalat buah pada tanaman jeruk gerga dengan mengumpulkan buah yang jatuh setiap 7 hari dimulai dari hari pertama lampu dinyalakan. Tanaman perlakuan dipilih secara sengaja (Purposive). Tanaman utama (tanaman dipasangi lampu LED = TL), tanaman yang posisinya terdekat dengan tanaman utaman $(\mathrm{TL})=\mathrm{TL}+1$, tanaman yang posisinya terdekat dengan $\mathrm{TL}+1=$ TL+2, dan beberapa tanaman lain yang jauh dari posisi tanaman berlampu tetapi masih satu hamparan kebun sebagai kontrol. Pola seperti ini diulang 5 kali sehingga secara keseluruhan membentuk rancangan yang seragam, tetapi secara umum akan membentuk kelompok (blok) akan tetapi perlakuan (TL, TL+1, TL+2,) posisinya sama (tidak acak) karena posisi menjadi perlakuan. Data hasil pengamatan dianalisis secara statistik dengan analisis varians (ANAVA) menggunakan uji $\mathrm{F}$ taraf 5\%. Hasil uji $\mathrm{F}$ yang menunjukan pengaruh nyata diuji lanjut dengan menggunakan Beda Nyata Terkecil (BNT) pada taraf 5\%. Dari hasil penelitian dapat disimpulkan bahwa penggunaan cahaya lampu LED sebagai repellent dapat menurunkan tingkat serangan penggerek buah, namun tidak berpengaruh pada serangan lalat buah.
\end{abstract}

Kata Kunci : Jeruk RGL, Lampu LED, Penggerek Buah

\section{Abstract}

This study aims to evaluate the effectiveness of LED light + reflector (compact disc) as an alternative to control fruit borer on RGL oranges and their effect on the incidence of fruit fly attacks in PAL VII Village, Bermani Ulu Raya District, Rejang Lebong Regency, Bengkulu Province, land height is $\pm 1000 \mathrm{~m}$ above sea level. Citrus plants were 6 years old when the research was carried out, were already producing and well maintained with a spacing of $5 \times 5$ meters. Lights were given to the sample plants at several observation points at the research site. The lights that have been installed are turned on every day from 18.00-06.00 WIB from August 10 to November 10, 2020. Then, the attack of borers and fruit flies on the citrus plant is carried out by collecting fallen fruit every 7 days starting from the first day the lights are turned on. The treatment plants were selected intentionally (purposively). Main plants (plants with LED lights = $T L)$, plants whose position is closest to the main plant $(T L)=T L+1$, plants whose position is closest to $T L+1=T L+2$, and several other plants that are far from the position of lighted plants but still one stretch of garden as Control. This pattern is repeated 5 times so that overall it forms a uniform design, but in general it will form a group (block) but the treatments $(T L, T L+1, T L+2$, ) 
Prosiding Seminar Nasional Pembangunan dan Pendidikan Vokasi Pertanian

Politeknik Pembangunan Pertanian Manokwari, 31 Juli 2021

e ISSN : 2774-1982

DOI : https://doi.org/10.47687/snppvp.v2i1.176

are in the same position (not random) because the position becomes the treatment. The results of the observations were analyzed statistically by analysis of variance (ANOVA) using the F test at $5 \%$ level. The results of the F test which showed a significant effect were further tested using the Least Significant Difference (BNT) at the 5\% level. From the results of the study it can be concluded that the use of LED light as a repellent can reduce the level of fruit borer attacks, but has no effect on fruit fly attacks.

Keywords: Fruit Borer, LED Light, RGL Oranges

\section{PENDAHULUAN}

Tanaman jeruk merupakan tanaman tahunan yang mempunyai peranan penting di pasaran dunia maupun dalam negeri, baik dalam bentuk buah segar atau bentuk olahan (Kementerian Pertanian, 2011). Indonesia mempunyai berbagai macam varietas jeruk, salah satunya yang mulai dikembangkan secara nasional adalalah jeruk gerga lebong (varietas/klon RGL). Jeruk RGL telah dijadikan komoditi andalan dan saat ini dikembangkan di tiga kabupaten yaitu kabupaten Lebong, Rejang Lebong dan Kepahiang. Data terakhir yang diterbitkan oleh BPS tahun 2018, berkaitan dengan luas panen jeruk siam/keprok di provinsi Bengkulu telah meningkat dari tahun sebelumnya yaitu mencapai 370 hektar, walau sempat naik turun pada 2014 hingga 2017.

Jeruk RGL yang awalnya dikembangkan di kabupaten Lebong sekarang telah terdaftar sebagai klon unggulan nasional. Keunggulan tersebut meliputi warna buah (kuning-orange), masa berbuah sepanjang tahun, ukuran buah besar (200-350/gram), rasa buah asam manis segar dan kadar sari buah yang tinggi (Rambe et al., 2012). Hasil analisis buah lebih lanjut menunjukan sifat fisik dan kimia yaitu total padatan terlarut (TPT) berkisar antara 12-16 Brix, mengandung 89,20\% air, 0,92\% asam, dan 18,34 $\mathrm{mg} / 100$ gram vitamin C (Mikasari et al., 2015).

Dua jenis hama yang sering menimbulkan kerusakan pada buah jeruk RGL adalah penggerek buah jeruk (Citripestis sagitiferella) dan lalat buah (Bactrocera sp.) (Agustina, 2015). Insidensi kedua spesies hama tersebut, menyebabkan kehilangan hasil dan penurunan kualitas, dan sering menyebabkan kerugian ekonomi ditingkat petani. Teknologi pengendalian hama untuk lalat buah yang aman terhadap lingkungan sebenarnya sudah tersedia secara lokal, dan beberapa petani jeruk telah mengimplementasikannya, akan tetapi belum dilakukan secara merata oleh semua petani. Sebaliknya teknologi untuk pengendalian populasi penggerek buah jeruk sampai saat ini masih sangat tergantung pada penggunaan insektisida kimia. Sifat hidup larva yang 
Prosiding Seminar Nasional Pembangunan dan Pendidikan Vokasi Pertanian

Politeknik Pembangunan Pertanian Manokwari, 31 Juli 2021

e ISSN : 2774-1982

DOI : https://doi.org/10.47687/snppvp.v2i1.176

tersembunyi di dalam buah menjadikan hama ini sulit dikendalikan dengan aplikasi insektisida (Agustina, 2015).

Agustina (2015) melaporkan bahwa insidensi hama lain pada tanaman jeruk RGL masih tergolong rendah dibandingkan dengan serangan $C$. sagittiferella. Karena jika dilihat dari pola fluktuatif serangan dan jumlah larva yang ada belum tampak adanya pengaruh terhadap pengendalian kimiawi yang dilakukan oleh petani setiap 10-14 hari, mengindikasikan kekurang efektifan aplikasi insektisida yang dilakukan petani. Banyak faktor yang menyebabkan aplikasi insektisida tidak efektif, termasuk di antaranya tidak mengenai sasaran (misalnya larva sudah berada di dalam buah), atau terjadi peningkatan resistensi serangga hama sasaran. Kemungkinan terakhir ini diperkuat hasil peneitian Saputra (2019) yang menguji dua insektisida yang berbahan aktif biologi, Abamectein dan Bacillus thuringiensis. Hasilnya menunjukkan bahwa efektifitas Abametin untuk mengendalikan penggerek sangat nyata lebih rendah dibandingkan dengan $B$. thuringiensis. Abamectin adalah insektisida yang sekaligus bersifat acarisida, yang sudah biasa digunakan oleh petani jeruk setempat. Hasil penelitian yang dilakukan di Vietnam pada jeruk Pamelo (Dien et al., 2013), menunjukan bahwa lampu fluorescent dapat menghalau/mencegah (bersifat repellent) ngengat betina untuk meletakkan telur pada buah jeruk. Pemasangan lampu fluoescent pada malam hari menurunkan tingkat kerusakan buah sampai $100 \%$ dan secara ekonomi lebih efisien (menghemat biaya dan meningkatkan keuntungan) dibandingkan dengan penggunaan insektisida kimia. Penggunaan lampu fluorescent belum pernah dilakukan di sentra jeruk RGL di Bengkulu. Perkembangan teknologi perlistrikan dengan ditemukannya bola lampu listrik yang lebih hemat energi, yaitu Light Emitted Diode (LED) mungkin bisa lebih efisien untuk menekan insidensi serangan $C$. sagittiferella pada jeruk RGL, karena lampu LED terang dan hemat energi dibandingkan dengan lampu fluorescent. Dilapangan sampai saat ini penggunaan pestisida untuk pengendalian hama penggerek buah masih menjadi pilihan utama bagi petani dan belum ada alternatif lain yang aman terhadap lingkungan. Sedangkan penggunaan pestisida yang intensif dapat dampak negatif terhadap ekosistem dan dalam jangka panjang dapat merugikan bagi petani. Selain itu, biaya pengaplikasian pestisida yang terus menerus dinilai kurang ekonomis untukbudidaya jeruk RGL berkelanjutan. Hasil penelitian Agustina (2015) dan Saputra (2019) menunjukkan hal itu. Merujuk dari hasil penelitian yang dilakukan Dien et al. (2013) yang menemukan metode yang efektif dan lebih aman terhadap lingkungan, maka perlu dilakukan penelitian di 
Prosiding Seminar Nasional Pembangunan dan Pendidikan Vokasi Pertanian

Politeknik Pembangunan Pertanian Manokwari, 31 Juli 2021

e ISSN : 2774-1982

DOI : https://doi.org/10.47687/snppvp.v2i1.176

sentra jeruk RGL untuk mengendalikan spesies hama yang sama yang menjadi salah satu utama yang sulit dikendalikan dengan insektisida. Peggunaan lampu LED lebih hemat energi dibandingkan dengan lampu fluorescent diharapkan memberikan hasil yang lebih hemat biaya. Karena itu tujuan dari penelitian ini untuk mengevaluasi efektifitas cahaya lampu LED + reflector (compact disc) sebagai salah satu alternatif untuk mengendalikan penggerek buah pada jeruk RGL dan pengaruhnya terhadap insidensi serangan lalat buah.

\section{METODE}

Penelitian dilaksanakan pada bulan Agustus -November 2020 di kebunjeruk RGL milik Bapak Darlin di desa PAL VII, kecamatan Bermani Ulu Raya, kabupaten Rejang Lebong, provinsi Bengkulu. Lahan berada pada 1000 mdpl. Seluruh luasan kurang lebih 1,5 hektar dengan topografi landai - miring. Pada saat penelitian diakukan, tanaman jeruk sudah berumur 6 tahun sudah berproduksi dengan kondisi kebun terawat baik, bersih dari gulma. Tanaman jeruk ditanam dengan jarak tanam $5 \mathrm{~m} \times 5 \mathrm{~m}$. Pemangkasan tunas baru dilakukan sekitar 20-30 hari sekali tergantung pertumbuhan tunas baru. Pengendalian OPT dilakukan oleh petani pemilik kebun setiap 10-15 hari sekali, menggunakan insektisida sintetik yang berbahan aktif abamektin (1-1,5 $\mathrm{ml} / \mathrm{l})$, profenofos $(1,5-2 \mathrm{ml} / \mathrm{l})$ dan fungisida berbahan aktif mankozeb (10-20g/l). Lingkungan sekitar kebun banyak ditanami tanaman jeruk RGL, jeruk Berastagi dan kopi Robusta. Kebun lokasi penelitian ditanami tanaman cabai hibrida varietas Rinta F1 di sela-sela tanaman jeruk. Di Rejang Lebong, tanaman jeruk RGL berbuah sepanjang tahun, puncak panen (panen besar) terjadi pada bulan Mei dan Oktober. Penelitian ini bersifat kulitatif dan kunatitatif, tanaman perlakuan dipilih secara sengaja (purposive). Tanaman utama (tanaman dipasangi lampu LED $=\mathrm{TL})$, tanaman yang posisinya terdekat dengan TL $(\mathrm{TL}+1)$, tanaman yang posisinya terdekat berikutnya $(\mathrm{TL}+2)$, dan tanaman lain yang jauh dari posisi tanaman berlampu tetapi masih sederetan dengan TL dan TL+ digunakan sebagai tanamn (Kontrol). Pola seperti ini diulang 5 kali sehingga secara keseluruhan membentuk rancangan yang seragam, tetapi secara umum akan membentuk kelompok (blok) akan tetapi perlakuan (TL, TL+1, TL+2, dan Kontrol) posisinya sama (tidak acak) pada setiap ulangan. Dengan demikianrancangan percobaan yang digunakan menyerupai rancangan kelompok (block), tetapi tidak acak, karena posisi tanaman perlakuan (menggambarkan kekuatan cahaya LED) sama untuk semua ulangan. Diasumsikan faktor-faktor lain seperti kesuburan tanah, iklim, paparan cahaya matahari, serta perawatan dan menejemen kebun lainya adalah sama, sehingga homogen pada semua faktor, selain faktor yang diteliti 
Prosiding Seminar Nasional Pembangunan dan Pendidikan Vokasi Pertanian

Politeknik Pembangunan Pertanian Manokwari, 31 Juli 2021

e ISSN : 2774-1982

DOI : https://doi.org/10.47687/snppvp.v2i1.176

untuk diketahui perbedaanya, yaitu cahaya lampu LED pada malam hari. Lampu LED (Philips dengan kapasitas 5 watt) dengan tingkat keterangan mencapai 540 Lumen dan cahaya berwarna putih (cool daylight - cahaya putih) dipasang pada tanaman TL pada ketinggian 2,5 m. Semua lampu dihubungkan dengan sumber listrik dengan kabel NGA. Compact disc (CD) bekas dipasang pada masing-masing TL sebanyak 4 buah sebagai reflektor dimaksudkan untuk menambah tingkat gangguan pada ngengat penggerek buah jeruk. Lampu yang telah dipasang dinyalakan setiap hari dari pukul 18.00-06.00 WIB dari tanggal 10 Agustus sampai 10 November 2020. Pengamatan serangan penggerek buah dan lalat buah pada tanaman sampel (yang digunakan sebagai tanaman percobaan) dilakukan dengan mengumpulkan buah yang jatuh karena terserang hama, sekali setiap 7 hari dimulai dari hari pertama lampu dinyalakan.

Pengamatan serangan lalat buah juga dilakukan untuk mengetahui apakah penggunaan lampu untuk mengganggu perilaku pencarian inang dari penggerek buah berpengaruh terhadap perilku hama lain, karena penggunaan lampu sebagai repellent dikhawatirkan akan mengundang lalat buah yang juga merupakan salah satu hama utama.

\section{HASIL DAN PEMBAHASAN}

\section{Gambaran Umum Lokasi Penelitian}

Selama penelitian ini dilakukan, curah hujan dan hari hujan yang terjadi bervariatif. Curah hujan selama berlangsungnya penelitian termasuk tinggi yaitu $103 \mathrm{~mm}$ (5 hari hujan) pada bulan Agustus, 376 mm (14 hari hujan) pada bulan September, 644 mm (28 hari hujan) bulan Oktober, dan 363 mm (19 hari hujan) pada bulan November (Lampiran 2).

Tingkat serangan hama dipengaruhi oleh berbagai faktor, diantaranya yaitu kondisi lingkungan seperti ketinggian tempat, suhu, kelembaban dan curah hujan. Populasi larva C. Sagitiferella berkurang seiring dengan pertambahan ketinggian tempat dan penurunan suhu. Penurunan suhu menyebabkan penurunan laju reproduksi serangga, sehingga populasi serangga pun akan menurun seiring dengan penurunan suhu di lingkungannya. Jumlah serangan penggerek buah lebih tinggi pada saat curah hujan tinggi dibandingkan saat curah hujan rendah. Curah hujan yang tinggi meningkatkan kelembapan tanah, sehingga menjadi kondisi ideal bagi pupa $C$. sagitiferella yang berada di bawah permukaan tanah untuk menetas menjadi serangga dewasa kemudian kawin dan meletakkan telur pada buah jeruk (Muryati, 2007; Ardhana dan Gede, 2012; Hoiss et al., 2012; Dinata dan Rambe, 2013; Rahayu et al., 2018). 
Prosiding Seminar Nasional Pembangunan dan Pendidikan Vokasi Pertanian

Politeknik Pembangunan Pertanian Manokwari, 31 Juli 2021

e ISSN : 2774-1982

DOI : https://doi.org/10.47687/snppvp.v2i1.176

Kandungan minyak dapat menurunkan jumlah serangan hama penggerek buah. Kandungan atsiri pada kulit jeruk lebih rendah (0,22\%) pada curah hujan tinggi dibandingkan curah hujan rendah $(0,24 \%)$. Konsentrasi senyawa dominan (limonen) saat curah hujan tinggi lebih tinggi (91,43\% dari total senyawa atsiri yang ada) dibandingkan curah hujan rendah $(73,26 \%)$, sehinggajumlah serangan $C$. sagitiferella lebih tinggi pada curah hujan tinggi dibandingkan pada saat curah hujan rendah (Muryati, 2007).

Kedua pendapat tersebut bertentangan dengan hasil penelitian yang terjadi di lapangan. Saat memasuki bulan dengan curah hujan tinggi, jumlah serangan penggerek buah pada tanaman yang diberikan perlakuan lampu justru menurun, bahkan tidak terjadi serangan sama sekali hingga penelitian selesai dilaksanakan.

Pengaruh Perlakuan Cahaya Lampu LED Terhadap Tingkat Serangan Penggerek

\section{Buah C. Sagittiferella}

Dari percobaan yang telah dilakukan, pemberian cahaya buatan sebagai repellent dapat menurunkan jumlah serangan penggerek buah, walaupun kondisi lingkungan terutama curah hujan yang tinggi seharusnya cukup mendukung perkembangan penggerek buah.

Tabel 1. Data hasil analisis varian

\begin{tabular}{lllll}
\hline \multicolumn{1}{c}{ AMATAN } & FHIT & \multicolumn{1}{c}{ KK $(\%)$} & & SIGNIFIKASI \\
\hline Minggu 3 & 17.6 & 68.04 & $*$ & \\
\hline Minggu 7 & 16 & 111.80 & $*$ & \\
\hline Minggu 8 & 5 & 200 & $*$ & \\
\hline
\end{tabular}

Dari pengamatan yang telah dilakukan selama 12 minggu menunjukkan bahwa pemberian cahaya buatan berupa lampu LED berpengaruh nyata terhadap jumlah serangan penggerek buah pada minggu ke 3, 7, dan 8 saja, sisanya berpengaruh tidak nyata terhadap jumlah serangan penggerek buah. 


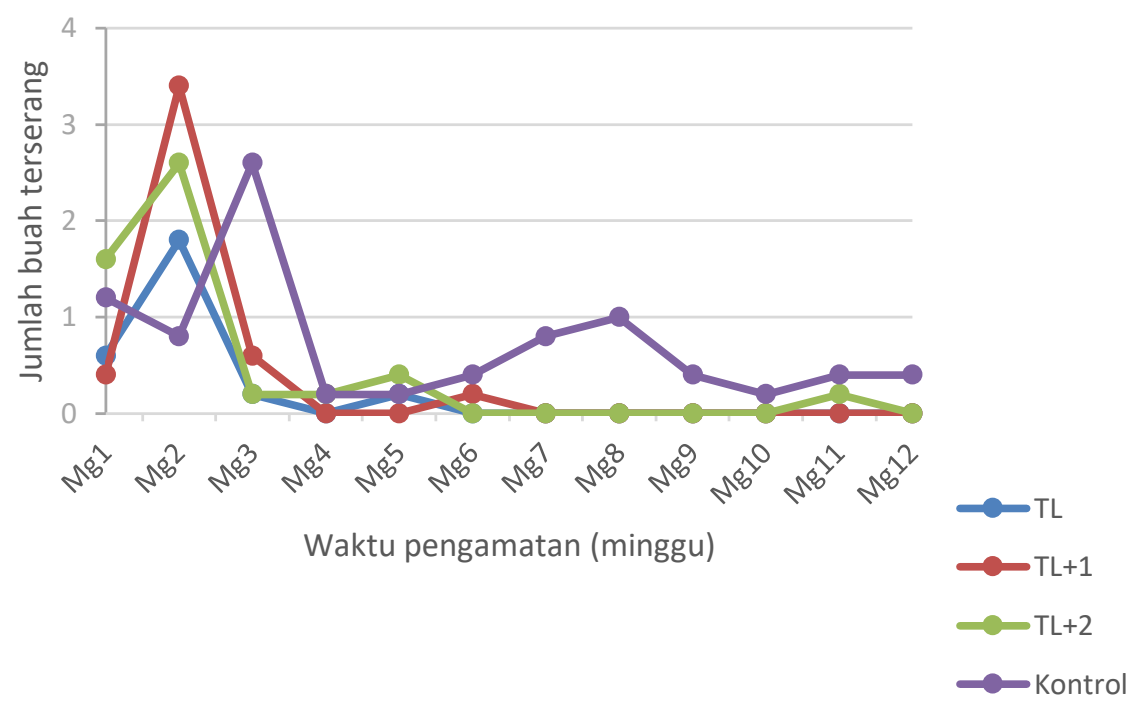

Gambar 1. Fluktuasi jumlah buah terserang $C$. Sagittiferella pada posisi relatif terhadap lampu LED selama 12 minggu pengamatan bulan Agustus - Oktober 2020

Serangan penggerek buah cenderung menurun dari minggu 2 ke minggu-minggu selanjutnya, tetapi hal ini mungkin lebih disebabkan oleh pengendalian yang dilakukan dengan pestisida. Meskipun demikian, tampak jelas bahwa tanaman TL lebih rendah dibandingkan dengan tanaman pada posisi yang lebih berjauhan dengan lampu LED.

Gambar 1 menunjukkan bahwa pada awal pengamatan, jumlah serangan tertinggi terdapat pada tanaman kontrol dan TL+2 yang mendapat cahaya paling sedikit. Pada pengamatan selanjutnya, terjadi peningkatan pada perlakuan yang diberikan pencahayaan, sedangkan kontrol menurun. Pada minggu ketiga, jumlah serangan penggerek buah pada tanaman yang diberikan cahaya buatan mulai menurun, sehingga jumlah serangan penggerek buah pada tanaman kontrol secara umum lebih tinggi dan terus berlanjut hingga pengamatan terakhir dilakukan.

Pada minggu keempat jumlah serangan penggerek buah hampir mendekati nol termasuk pada kontrol. Hal ini terjadi karena beberapa hari sebelumnya dilakukan penyemprotan pestisida pada lokasi tanaman kontrol, sehingga jumlah serangan penggerek buah pun menurun. Sesuai dengan hasil penelitian Saputra (2019), pengaplikasian insektisida berbahan aktif abamektin dapat menurunkan jumlah serangan penggerek buah pada tanaman jeruk. Dengan adanya cahaya buatan ditambah penyemprotan insektisida, maka serangan hama penggerek buah dapat ditekan hingga 
Prosiding Seminar Nasional Pembangunan dan Pendidikan Vokasi Pertanian

Politeknik Pembangunan Pertanian Manokwari, 31 Juli 2021

e ISSN : 2774-1982

DOI : https://doi.org/10.47687/snppvp.v2i1.176

sekecil mungkin, walaupun ada penambahan yang cukup signifikan pada minggu ke-7 dan ke-8 pada tanaman kontrol, namun tanaman yang diberikan cahaya buatan tidak ada penambahan jumlah serangan yang signifikan hingga pengamatan terakhir.

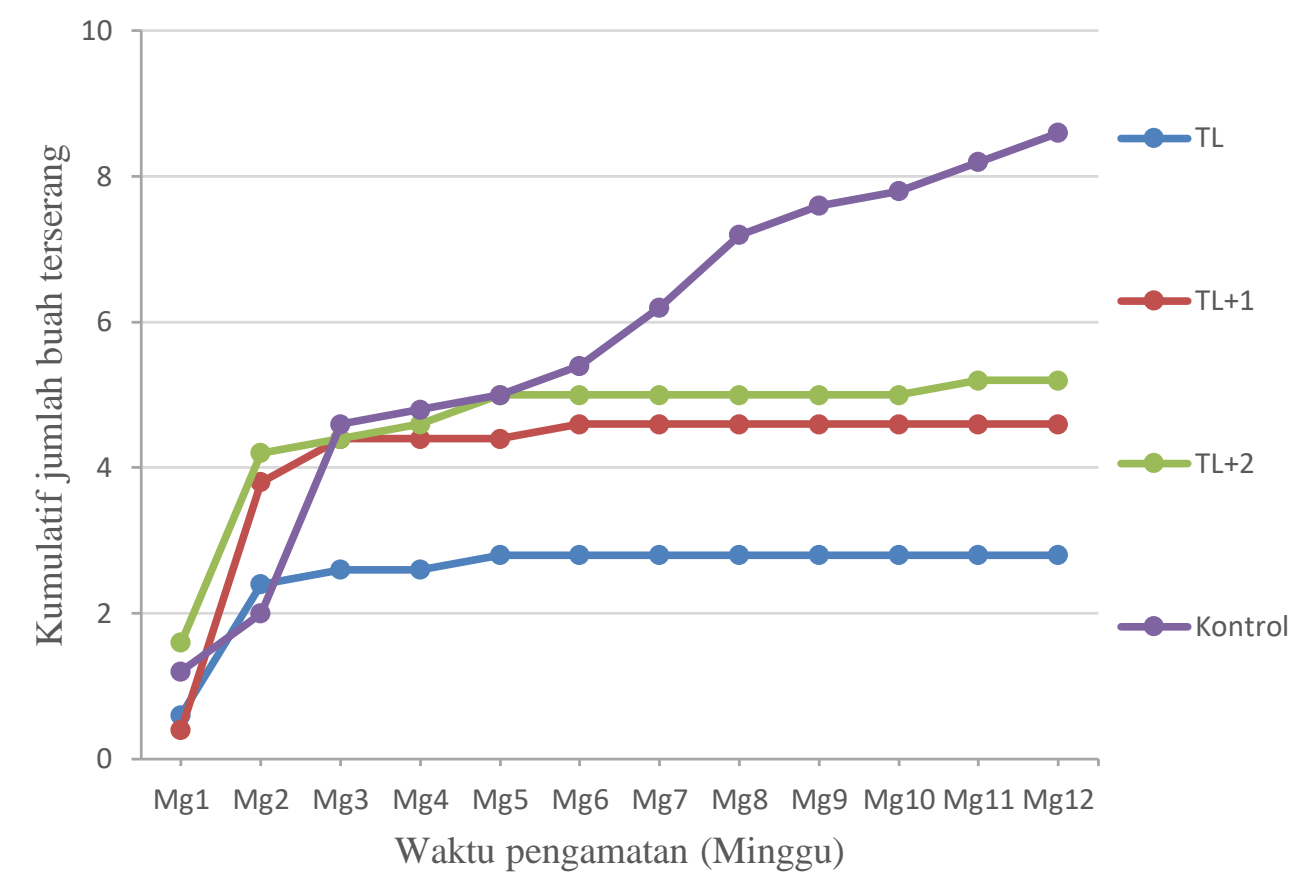

Gambar 2. Kumulatifjumlah buah terserang C. Sagittiferella pada posisi relatif tanaman terhadap lampu LED selama 12 minggu pengamatan bulan Agustus - Oktober 2020

Gambar 2 menunjukkan bahwa gambar kumulatif jumlah buah terserang memperlihatkan dengan jelas tanaman dengan lampu LED mendapat serangan penggerek buah yang lebih ringan dari pada tanaman dengan posisi relative tanaman yang semakin jauh dari lampu LED.

Nilai kumulatif buah terserang penggerek pada tanaman yang diberikan cahaya buatan tidak mengalami kenaikan dari munggu ke-6 hingga minggu terakhir pengamatan dilakukan. Artinya tidak ada penambahan jumlah serangan penggerek hingga penelitian selesai dilakukan, sedangkan pada tanaman kontrol, jumlah kumulatif serangan penggerek masih mengalami kenaikan. Dapat diartikan bahwa pemberian cahaya buatan pada tanaman dapat mencegah penggerek buah untuk datang dan menetaskan telurnya di permukaan kulit buah jeruk. (Dien et al., 2013). 
Prosiding Seminar Nasional Pembangunan dan Pendidikan Vokasi Pertanian

Politeknik Pembangunan Pertanian Manokwari, 31 Juli 2021

e ISSN : 2774-1982

DOI : https://doi.org/10.47687/snppvp.v2i1.176

Secara umum, jumlah serangan penggerek buah paling rendah terdapat pada perlakuan $\mathrm{TL}$, disusul oleh $\mathrm{TL}+1$ dan $\mathrm{TL}+2$. Ini artinya jarak tanaman darisumber cahayadapat mempengaruhi jumlah serangan yang diterima, walaupun berbeda tidak nyata.

Intensitas Serangan Lalat Buah (Bactrocera spp.) Terhadap Hasil Tanaman Jeruk RGL

Penggunaan cahaya buatan yang diharapkan dapat mengendalikan hama penggerek buah tentunya dapat dikatakan berhasil apabila cahaya tersebut tidak mengundang hama utama lain bagi tanaman jeruk yaitu lalat buah.

Pada penelitian ini serangan lalat buah tidak begitu diperhitungkan, karena lampu LED sebagai repellent digunakan hanya pada malam hari yaitu dari pukul 18.00-06.00. Sedangkan menurut Hasyim et al. (2014), lalat buah dewasa akan aktif terbang pada pukul 06:00-09:00 atau sore hari pukul 15:00-18:00, sehingga tidak berkaitan dengan penggunaan lampu LED tersebut. Gambar berikut hanya menunjukkan kondisi serangan lalat buah selama penelitian dilaksanakan.

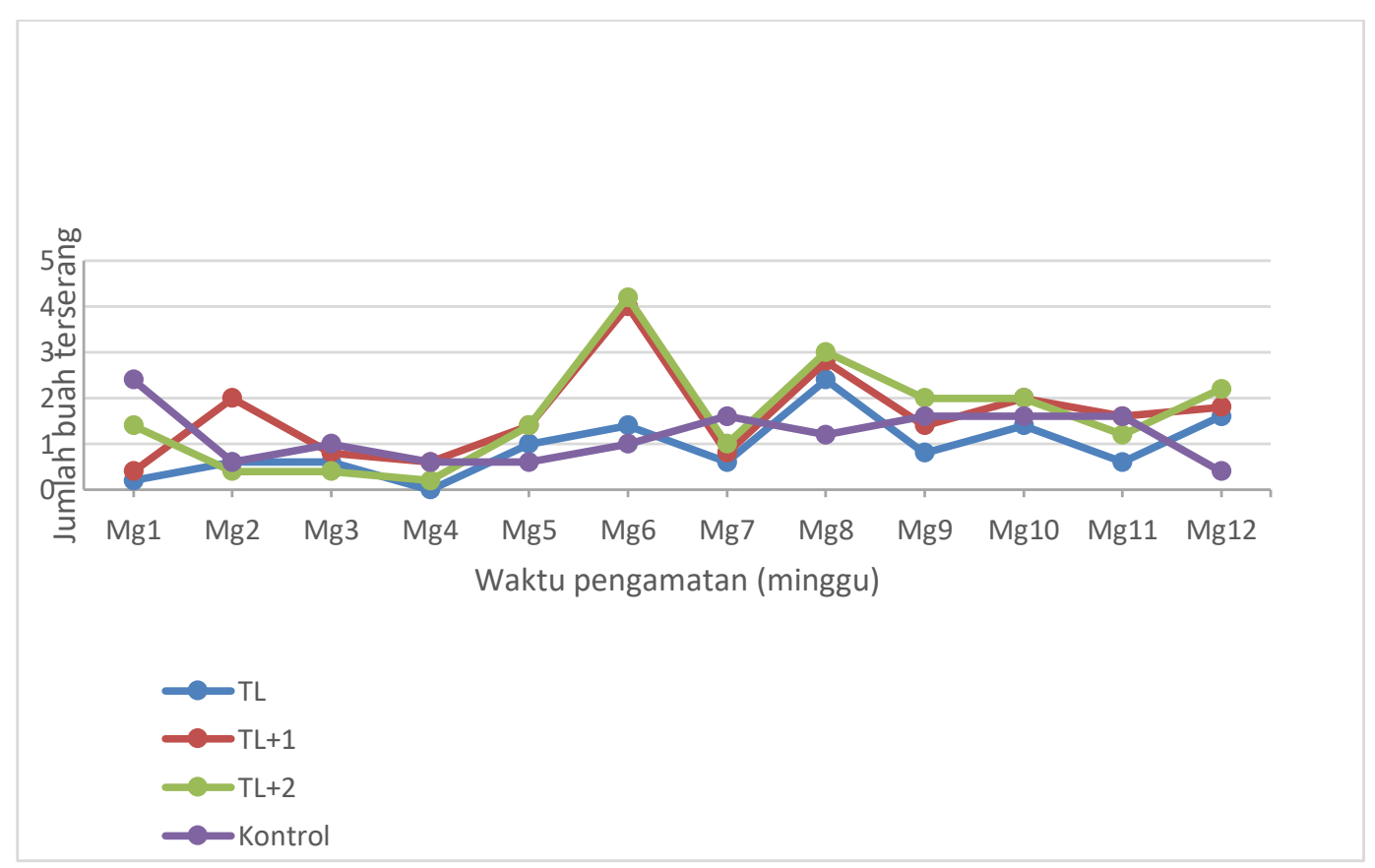

Gambar 3.Fluktuasi perkembangan jumlah buah terserang Bactrocera spp. Pada posisi relatif tanaman terhadap lampu LED selama 12 minggu pengamatan bulan AgustusOktober 2020 
Prosiding Seminar Nasional Pembangunan dan Pendidikan Vokasi Pertanian

Politeknik Pembangunan Pertanian Manokwari, 31 Juli 2021

e ISSN : 2774-1982

DOI : https://doi.org/10.47687/snppvp.v2i1.176

Secara umum ada kecenderungan peningkatan tingkat serangan lalat buah. Pengaruh cahaya lampu LED jelas menunjukkan lampu LED tidak berpengaruh pada lalat buah yang aktif pada sianghari.

Gambar 3 menunjukkan bahwa jumlah serangan lalat buah di awal dan pertengahan penelitian cukup tinggi, namun di akhir penelitian menurun namun fluktuatif, menegaskan bahwa pemberian cahaya buatan memang tidak berpengaruh terhadap lalat buah.

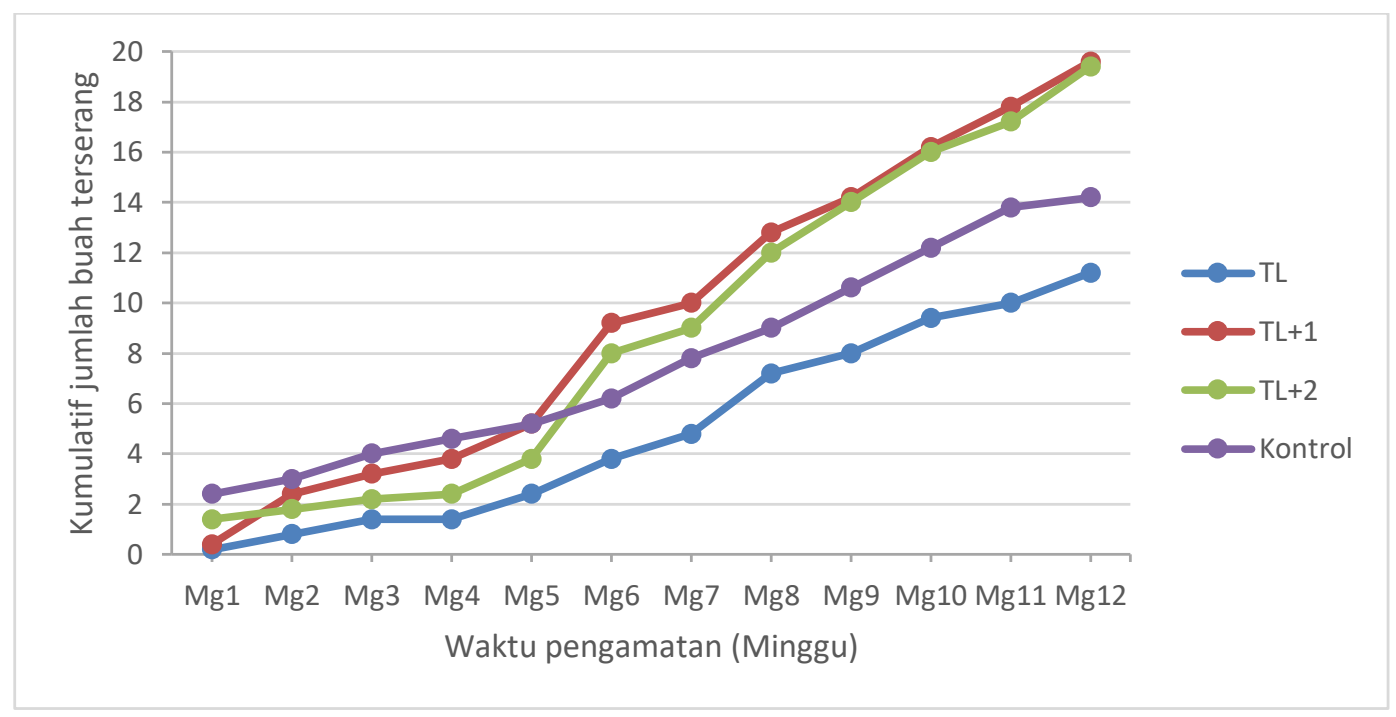

Gambar 4. Kumulatif jumlah buah terserang Bactrocera spp. pada posisi relatif tanaman terhadap lampu LED selama 12 minggu pengamatan bulan Agustus - Oktober 2020

Gambar 4 menunjukkan bahwa dari awal penelitian hingga akhir, jumlah serangan lalat buah pada tanaman jeruk terus bertambah, baik pada tanaman yang diberikan cahaya buatan maupun yang tidak. Ini menegaskan bahwa pemberian cahaya buatan memang tidak berpengaruh terhadap lalat buah, ini dikarenakan lalat buah memang aktif pada pagi hingga sore hari (Siwi dan Hidayat, 2004; Manurung et al., 2012).

Meskipun demikian dari kumulatif jumlah buah terserang lalat buah pada tanaman dengan lampu LED juga lebih rendah dibandingkan dengan tanaman pada posisi relatif yang lebih berjauhan dengan lampu TL, hanya saja polanya tidak konsisten, karena tanaman yang paling jauh dari lampu LED justru lebih rendah tingkat serangannya dibandingkan dengan tanaman pada posisi relative yang lebih berdekatan dengan lampu LED. 
Prosiding Seminar Nasional Pembangunan dan Pendidikan Vokasi Pertanian

Politeknik Pembangunan Pertanian Manokwari, 31 Juli 2021

e ISSN : 2774-1982

DOI : https://doi.org/10.47687/snppvp.v2i1.176

\section{Total Buah Terserang}

Total buah terserang merupakan akumulasi buah yang telah rusak akibat serangan hama, baik itu Penggerek Buah, maupun serangan Lalat Buah. Berdasarkan pengamatan yang dilakukan, jumlah buah yang terserang oleh lalat buah jauh lebih tinggi daripada hama penggerek buah. Ini diakibatkan karena penelitian hanya berfokus untuk mengendalikan serangan penggerek buah, sedangkan pengendalian serangan lalat buah tidak dilakukan.

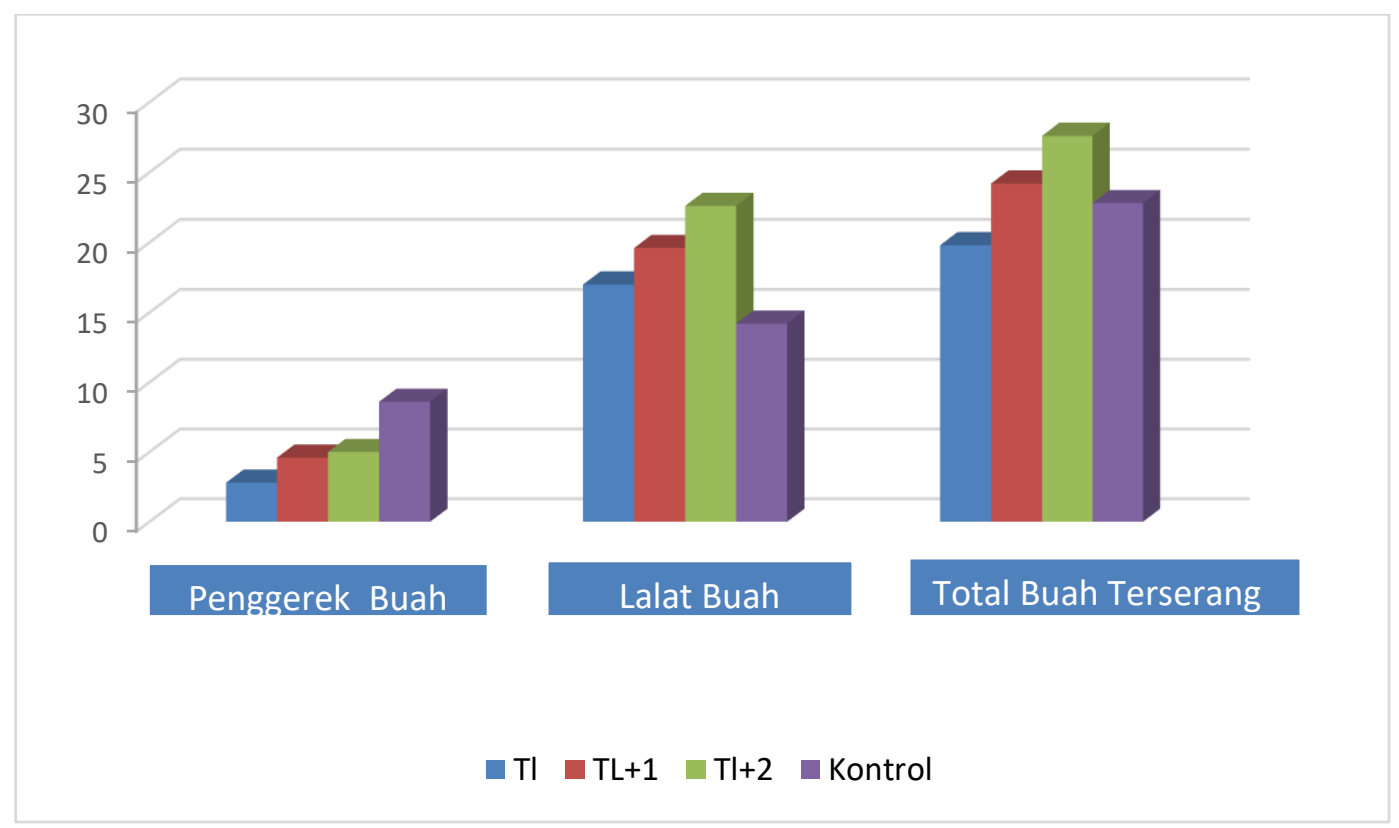

Gambar 6. Jumlah buah terserang penggerek buah dan lalat buah dan total dari kedua jenis hama selama pada posisi relatif tanaman terhadap lampu LED selama 12 minggu pengamatan pada bulan Agustus-Oktober 2020

Pemanfaatan cahaya lampu LED dinilai dapat menurunkan tingkat serangan penggerek buah pada jeruk RGL, namun tidak berpengaruh terhadap serangan lalat buah. Namun belum diketahui apakah pemanfaatan cahaya buatan tersebut memiliki dampak negatif terhadap serangga lain yang merupakan musuh alami hama utama jeruk RGL atau tidak, sehingga belum bisa dipastikan apakah aplikasi lampu LED ini merupakan cara yang paling tepat untuk mengatasi permasalahan serangan hama utama tanaman jeruk tersebut.

\section{KESIMPULAN DAN SARAN}

Penggunaan cahaya lampu LED sebagai repellent dapat menurunkan tingkat serangan penggerek buah, namun tidak berpengaruh pada serangan Lalat buah. Perlu penelitian lanjutan untuk mengetahui kebutuhan lampu, kabel dan perangkat yang 
Prosiding Seminar Nasional Pembangunan dan Pendidikan Vokasi Pertanian

Politeknik Pembangunan Pertanian Manokwari, 31 Juli 2021

e ISSN : 2774-1982

DOI : https://doi.org/10.47687/snppvp.v2i1.176

dibutuhkan serta perhitungan biaya untuk mengendalikan serangan penggerek buah pada tanaman jeruk menggunakan cahaya buatan.

\section{UCAPAN TERIMA KASIH}

Terimakasih kepada bapak Prof. Dr. Ir. Dwinadi apriyanto, M.Sc. sebagai dosen pembimbing utama dalam penulisan ini dan bapak Ir. Supanjani, M.Sc.,Ph.D sebagai pembimbing pendamping, serta bapak Agustin,SP.,M.Si.,Ph.D. dan bapak Ir. Eko Suprijono, MP. sebagai Tutor yang selalu memberikan masukan dan saran sehingga penulisan ini bisa dilakukan hingga selesai.

Tak lupa pula saya ucapkan terimakasih yang sebesar-besarnya kepada kedua orang tua saya (bapak Sudiyanto- ibu Erita) dan istri saya (Nafia Gustari) yang selalu memberikan support, doa, bahkan bantuan dalam permasalahan biaya operasional selama penelitian ini dilakukan. Serta Keluarga besar Darlin Farm dimana telah bersedia penggunaan lahan perkebunan RGL miliknya sebagai tempat penelitian ini dilakukan.

\section{DAFTAR PUSTAKA}

Agustina, E. (2015). Isidensi Beberapa Jenis Serangga Hama Penting Pada Tanaman Jeruk Klon Gerga Dan Klon Brastagi Di Rimbo Pengadang Kabupaten Lebong. Program studi Agroekoteknologi, Jurusan Budidaya Pertanian, Fakultas Pertanian Universitas Bengkulu. Bengkulu.

Badan Pusat Statistik. (2018). Luas Panen Jeruk Siam/Keprok Menurut Provinsi, tahun 2014-2018. BPS dan Direktorat Jenderal Hortikultura. Jakarta.

Dien, L.Q., N.T.K. Thoa, N.V. Hoa, N.M. Chau \& N.T.T. Cuc. (2013). Infestation of pamelo fruit borer Citripestissagittiferella (Moore) (Lepidoptera: Pyralidae) in Vietnam and the effect of compact fluorescent lamp as a repellent. hal: 112-119. Proceeding of International Symposium on Superfruits: Myth or Truth?. Ho Chi Minh City, Vietnam, 1-3 July 2013.

Dinata, K \& S.S.M. Rambe. (2012). Identifikasi dan Status Serangan OPT Utama Pada Pertanaman Jeruk RGL di Kabupaten Lebong. Balai Pengkajian Teknologi Pertanian Bengkulu.

Direktorat Budidaya Tanaman Buah. (2010). Profil Jeruk Keprok. Direktorat Budidaya Tanaman Buah, Jakarta.

Dirjen Hortikultura. (2012). LAKIP Direktorat Jenderal Hortikultura Tahun 2012. Kementerian Pertanian.

Dwiastuti, M.E. \& A. Muharam. (2007). Riview Hasil Penelitian Teknologi Organisme Pengganggu Tumbuhan Jeruk di Balitjestro dan Aplikasinya di Lapang. Balai Penelitian Tanaman Jeruk Dan Buah Subtropika. Pusat Peneliatian dan Pengembangan Hortikultura. Jakarta. 
Prosiding Seminar Nasional Pembangunan dan Pendidikan Vokasi Pertanian

Politeknik Pembangunan Pertanian Manokwari, 31 Juli 2021

e ISSN : 2774-1982

DOI : https://doi.org/10.47687/snppvp.v2i1.176

Hastuti, N.P. (2006). Serangga herbivor yang berasosiasi dengan tanaman jeruk dan kerusakan yang disebabkannya di Desa Sunda Kelapa Kecamatan Pondok Kelapa Bengkulu Utara. Skripsi. Fakultas Pertanian. Universitas Bengkulu. Bengkulu (tidak dipublikasikan).

Hoiss, B., J. Krauss, S.G. Potts, S. Roberts \& I.S. Dewenter. (2012). Altitude acts as an environmental filter on phylogenetic composition, traits and diversity in bee communities. Proceedings of the Royal Society B. 279:.4447-4456. doi: http://dx.doi.org/10.1098/rspb.2012.1581.

Johansen, N.S., I. Va“nninen, D.M.P. Zevallos, A.I. Nissinen \& L. Shipp. (2011). In the light of new greenhouse technologies: 2. Direct effects of artificial lighting on arthropods and integrated pest management in greenhouse crops. Annals of Applied Biology, 159(1):1-27.

Kinoshita, M \& K. Arikawa. (2000). Colour constancy in the swallowtail butterfly Papilio xuthus. Journal of Exp Biology 203:3521-3530.

Manurung, B., P. Prastowo \& E.E. Tarigan. (2012). Pola aktivitas harian dan dinamika populasi lalat buah Bactrocera dorsalis complex pada pertanaman jeruk di dataran tinggi Kabupaten Karo Provinsi Sumatera Utara. Jurnal HPT Tropika, 12(2):103110.

Martasari, C. (2017). Pengenalan dan Identifikasi Spesies Jeruk. Balai Penelitian Tanaman Jeruk dan Buah Subtropika. Badan Penelitian dan Pengembangan Pertanian.

Matteson, N., I. Terry, A.A. Christensen \& C. Gilbert. (1992). Spectral efficiency of the western flower thrips, Frankliniella occidentalis. Journal of Insect Physiol $38: 453-459$.

Menzel, R. \& U. Greggers. (1985). Natural phototaxis and its relationship to colour vision in honeybees. Journal of Comp Physiol 157:311-321.

Mikasari, W., L. Ivanti, T. Hidayat, S. Hartati, \& U. Hamidi. (2014). Laporan akhir tahun pengkajian peningkatan nilai tambah aneka produk tanaman pangan dan hortikultura lokal unggulan Bengkulu. Badan Penelitian Dan Pengembangan Pertanian Balai Pengkajian Teknologi Pertanian Bengkulu. Bengkulu.

Mikasari. W., L. Ivanti, \& T. Hidayat. (2015). Kajian Penerapan Teknologi Pascapanen Jeruk RGL Melalui Optimasi Pencucian dan Penyimpanan. Laporan Akhir. Balai Pengkajian Teknologi Pertanian Bengkulu. Bengkulu.

Mukhlis. (2016). Penerapan lampu perangkap (light trap) dan ekstrak akar tuba untuk pengendalian hama penggerek batang kuning (Scirpophaga spp.) pada tanaman padi (Oryza sativa L). Jurnal Agrohita, 1(1): 1-5.

Muryati. (2007). Pengaruh umur buah dan faktor iklim terhadap serangan penggerek buah jeruk Citripestis sagitiferella Mr (Lepidoptera: Pyralidae). Jurnal Hortikultura, 17 (2): 188-195. 
Prosiding Seminar Nasional Pembangunan dan Pendidikan Vokasi Pertanian

Politeknik Pembangunan Pertanian Manokwari, 31 Juli 2021

e ISSN : 2774-1982

DOI : https://doi.org/10.47687/snppvp.v2i1.176

Nissinen, A., L. Kristoffersen \& O. Anderbrant. (2008). Physiological state of female and light intensity affect the host-plant selection ofcarrot psyllid, Trioza apicalis (Hemiptera: Triozidae). European Journals of Entomology 105:227-232.

Nuryandani, E. (2012). Persebaran dan karakterisasi induk jeruk keprok Tawangmangu asli (Citrus reticulata Blanco Ssp Tawangmangu). Jurnal Matematika, Sains, dan Teknologi, 13(1): 33-42.

Owens, A.C.S. \& S.M. Lewis. (2018). The impact of artificial light at night on nocturnal insects: a review and synthesis. Ecology and Evolution: 1-22. DOI: $10.1002 /$ ece3.4557.

Park, J.H. \& H.S. Lee. (2017). Phototactic behavioral response of agricultural insects and stored-product insects to light-emitting diodes (LEDs). Journal of the Korean Society for Applied Biological Chemistry, 60(2):137-144. 10.1007/s13765-0170263-2.

Purnomosidhi, P., Suparman \& R. Mulawarman. (2007). Perbanyakan dan Budidaya Tanaman Buah-buahan: Durian, Mangga, Jeruk, Melinjo, dan Sawo. World Agroforestry Centre and Winrock International. Bogor.

Rahayu, S.A.M.I.P., K.A. Yuliadhi, \& I.W. Susila. (2018). Persebaran, populasi dan persentase serangan Citripestis sagittiferella Moore (lepidoptera: pyralidae) di sentra pertanaman jeruk Provinsi Bali. Jurnal Agroekoteknologi Tropika, 7(3): 374-382.

Rahman, A.H., L. Aphrodyanti \& Salamiah. (2018). Uji preferensi beberapa warna lampu perangkap terhadap serangga padi lahan rawa pasang surut. Jurnal Proteksi Tanaman Tropika, 1(3): 71-75.

Rambe, S.S.M., A. Supriyanto, Afrizon, I. Calista, L. Ifanti, K. Dinata, B. Honorita \& Robiyanto. (2012). Pengkajian Teknologi Pembungaan Dan Pembuahan Jeruk Gerga di Lebong. Balai Pengkajian Teknologi Pertanian Bengkulu. Bengkulu.

Reisenman C.E., C.R. Lazzari \& M. Giurfa. (1998). Circadian control of photonegative sensitivity in the haematophagous bug Triatoma infestans. Journal of Com Physiol A, 183:533-541.

Ritung, S., K. Nugroho, A. Mulyani, \& E. Suryani. (2011). Petunjuk Teknis Evaluasi Lahan untuk Komoditas Pertanian (Edisi Revisi). Balai Besar Penelitian dan Pengembangan Sumberdaya Lahan Pertanian. Badan Penelitian dan Pengembangan Pertanian. Kementerian Pertanian. Bogor.

Saputra, M.A. (2019). Efektifitas bioinsektisida Bacillius thuringiensis dan abamectin untuk pengendalian penggerek buah jeruk Citripestis sagittiferella dan pengorok daun Phylocnistis citrella pada tanaman jeruk RGL. Skripsi. Program Studi Agroekoteknologi, Jurusan Budidaya Pertanian, Fakultas Pertanian, Universitas Bengkulu. Bengkulu.

Shimoda, M. \& K.I. Honda. (2013). Insect reactions to light and its applications to pest management. Applied Entomology and Zoology. DOI: 10.1007/s13355-013-0219$\mathrm{x}$. 